\title{
PELATIHAN PEMBUATAN AMONIASI JERAMI DI DESA MONTONG ARE KECAMATAN KEDIRI KABUPATEN LOMBOK BARAT
}

Didik Santoso'), Rully Bimantoro'), Ratna Sari Utami²), Baiq Ayu Nurhaliza3), Nurhadiah's), Anantiyas Hayatunnufus ${ }^{3)}$, Nihayah ${ }^{4)}$, Ramadiansyah Hakim ${ }^{5}$, M. Khaldun rachman ${ }^{2}$, Putri Nurul Fathiyyah2), Nia Anggraini2), Sagiri2)

1) Fakultas Keguruan dan IImu Pendidikan Universitas Mataram

2) Fakultas Ekonomi dan Bisnis Universitas Mataram

3) Fakultas Pertanian Universitas Mataram

4) Fakultas Teknik Universitas Mataram

5) Fakultas Hukum Universitas Mataram e-mail : didiksantoso@unram.ac.id

\begin{abstract}
ABSTRAK. Teknologi pengolahan pakan merupakan dasar teknologiuntuk mengolah limbah pertanian, perkebunan maupun agroindustri dalam pemanfaatannya sebagai pakan. Pengolahan pakan disini bertujuan untuk meningkatkan kualitas, utamanya efektifitas cerna, utamanya untuk ternak ruminansia serta peningkatan kandungan protein bahan. Beberapa alternatif pengolahan dapat dilakukan secara fisik (pencacahan, penggilingan dan atau pemanasan), kimia (larutan basa dan atau asam kuat), biologis (mikroorganisme atau enzim) maupun gabungannya. Pengolahan cara fisik dan biologis memerlukan tenaga dan investasi yang cukup tinggi dan dalam skala besar, sering kali menjadi tidak berjalan. Cara kimia dengan "amoniasi" dirasa merupakan cara yang paling tepat dalam pengolahan ini, karena mudah dilakukan, murah, tidak mencemari lingkungan dan sangat efisien. Pelatihan pembuatan amoniasi jerami dilakukan di Desa Montong Are, Kecamatan Kediri, Kabupaten Lombok Barat bertujuan untuk meningkatkan pengetahuan dan teknologi inovasi petani peternak tentang penggunaan jerami padi sebagai pakan dan bagaimana meningkatkan kualitasnya. Kualitas jerami padi termasuk total nitrogen dan daya cerna dapat ditingkatkan dengan teknologi amoniasi menggunakan urea. Penggunaan urea adalah 4\% untuk $100 \mathrm{~kg}$ jerami padi atau $4 \mathrm{~kg}$ untuk $100 \mathrm{~kg}$ jerami padi. Kegiatan ini dilakukan pada hari Kamis, 30 Agustus 2018. Metode yang digunakan adalah instruksi langsung dan praktik kepada petani. Hasil dari kegiatan ini menunjukkan bahwa pengetahuan para petani telah ditingkatkan dan para petani ingin menerapkan jerami padi yang telah diamoniasi sebagai pakan alternatif untuk ruminansia.
\end{abstract}

Kata kunci: jerami padi, amoniasi urea, kualitas pakan

ABSTRACT. Feed processing technology is the basis of technology for processing agricultural, plantation and agro-industrial waste in its use as feed. Processing of feed here aims to improve quality, especially the effectiveness of digestion, especially for ruminants and increasing protein content of ingredients. Some alternative processing can be done physically (enumeration, milling and or heating), chemistry (alkaline and / or strong acid solution), biological (microorganisms or enzymes) or their combinations. The processing of physical and biological methods requires considerable energy and investment on a large scale and often does not work. The chemical method with "ammonia" is considered to be the most appropriate way in this treatment, because it is easy to do, cheap, not pollute the environment and very efficient. The training in making straw 
ammonia was carried out in Montong Are Village, Kediri Subdistrict, West Lombok Regency, aimed at increasing the knowledge and innovation technology of farmers about the use of rice straw as feed and how to improve its quality. The quality of rice straw including total nitrogen and digestibility can be improved by using ammonia technology using urea. The use of urea is $4 \%$ for $100 \mathrm{~kg}$ of rice straw or $4 \mathrm{~kg}$ for $100 \mathrm{~kg}$ of rice straw. This activity is held on Thursday, August 30, 2018. The method used is direct instruction and practice for farmers. The results of this activity show that farmers' knowledge has been improved and farmers want to apply diamoniated rice straw as an alternative feed for ruminants.

Keywords: rice straw, urea ammonia, feed quality

\section{PENDAHULUAN}

Produksi jerami padi lebih dari 26 juta ton/tahun di Indonesia merupakan potensi ketersedian pakan ruminansia. Faktor pembatas jerami padi sebagai pakan yaitu kandungan protein rendah, silika, dan lignin yang berikatan dengan serat pakan (Novita et al., 2006). Jerami mempunyai beberapa kelemahan yaitu kandungan lignin dan silika yang tinggi tetapi rendah energi, protein, mineral dan vitamin. Selain rendah nilai nutrisi, kecernaan jerami juga rendah karena sulit didegradasi oleh mikroba rumen (Van Soest, 2006; Sarnklong et al., 2010). Selain hal tersebut diatas, kelemahan yang lain adalah karena jerami memiliki faktor pembatas seperti zat anti nutrisi (Mathius dan Sinurat, 2001) serta palatabilitasnya rendah (Tillman et al., 1998). Kecernaan yang rendah pada jerami padi merupakan akibat dari struktur jaringan penyangga tanaman yang sudah tua. Jaringan tersebut sudah mengalami proses lignifikasi, sehingga lignoselulosa dan lignohemiselulosa sulit dicerna (Balasubramanian, 2013). Untuk mengatasi hal tersebut maka amoniasi dapat dilakukan untuk meningkatkan kualitas jerami padi. Amoniasi akan meningkatkan kandungan nitrogen dalam pakan dan memecah ikatan lignin dengan serat pakan (Kraidees, 2005).

Desa Montong Are, Kecamatan Kediri, Kabupaten Lombok Barat merupakan desa yang berada di dataran tinggi, penduduknya sebagian besar bergerak di bidang pertanian dan peternakan. Ketersediaan jerami padi yang cukup tinggi belum dimanfaatkan secara optimal oleh petani peternak bahkan jerami padi sering dibakar sehingga terbuang percuma. Kondisi ini terjadi karena kurangnya pengetahuan petani peternak dalam memanfaatkan jerami padi sebagai pakan ternak ruminansia. Jerami padi dapat dimanfaatkan sebagai pakan ternak terutama pada saat musim kering, ketersediaan hijauan pakan ternak termasuk rumput terbatas dan sulit dicari.

\section{ANALISIS PERMASALAHAN}

Pemanfaatan jerami padi sebagai pakan ternak mengalami beberapa kendala antara lain, nilai nutrisinya yang rendah dibandingkan dengan rumput segar terutama dalam kandungan protein kasar dan mineral serta kecernaannya (Soejono, 1987). Sutrisno et al. (2006) menyatakan bahwa kandungan protein kasar jerami padi rendah (3-5\%), serat kasarnya tinggi (>34\%), kekurangan mineral, ikatan lignoselulosanya kuat dan kecernaannya rendah. Menurut Preston dan Leng (1987), rendahnya nilai nutrisi jerami padi disebabkan oleh kadar protein, kecernaan,mineral esensial dan vitamin yang rendah, serta kadar serat kasar yang tinggi.

\section{SOLUSI YANG DITAWARKAN}


Salah satu usaha untuk meningkatkan kualitas jerami padi dapat dilakukan dengan meningkatkan nilai cernanya melalui pemecahan ikatan kompleks lignoselulosa baik secara kimia, fisika, biologi maupun kombinasinya karena pakan merupakan faktor yang sangat menentukan berhasil tidaknya suatu usaha peternakan karena menyerap $60-80 \%$ dari total ongkos produksi. Pakan alternatif yang bisa digunakan adalah limbah pertanian seperti jerami padi yang biasanya tidak dimanfaatkan oleh petani peternak.

Pemecahan masalah tentang pemanfaatan jerami padi sebagai pakan ternak pada masyarakat di Desa Montong Are dilakukan dengan cara mengumpulkan masyarakat khususnya petani peternak. Kegiatan dilaksanakan pada hari Kamis, tanggal 30 Agustus 2018 di Kandang Sapi Kelompok Tani Ternak "Pade Pacu" Desa Montong Are, Kecamatan Kediri, Kabupaten Lombok Barat. Agar permasalahan yang ada dapat diatasi maka pada saat kegiatan penyuluhan dilaksanakan komunikasi dua arah yaitu melalui diskusi dan tanya jawab mengenai masalah yang ada dan berkembang di masyarakat petani peternak. Diskusi ini melibatkan petani peternak dan tim ahli dari Dinas Peternakan Lombok Barat.

Materi yang diberikan baik melalui penyuluhan dan diskusi serta tanya jawab meliputi : tata laksana pemeliharaan sapi, sumber pakan lokal alternatif, kandungan nutrisi jerami padi, teknologi pengolahan jerami padi dan kualitas jerami padi dengan amoniasi urea.

Semua peserta sangat serius dan bersemangat untuk mengikuti kegiatan terbukti dengan banyaknya peternak sapi yang mengikuti kegiatan ini terutama yang menyangkut tentang pakan termasuk teknologi pembuatan dan pemanfaatan jerami amoniasi, tata laksana pemeliharaan dan juga penyakit pada ternak sapi.

Pada saat kegiatan demonstrasi/pelatihan teknologi pembuatan jerami padi amoniasi semua peserta dengan antusias mengikuti pelatihan dengan berbagai pertanyaan yang mendetail sehingga menunjukkan kemauan yang tinggi untuk mempelajari hal/inovasi baru yang menguntungkan. Faktor pendorong keberhasilan kegiatan pengabdian adalah karena keingintahuan petani peternak akan inovasi teknologi pengolahan jerami padi ini sangat tinggi. Kualitas jerami yang diamoniasi memang lebih tinggi dibandingkan yang tidak diamoniasi (Tabel 1 dan Tabel 2). Kegiatan ini berdampak langsung pada petani peternak karena umumnya setiap peternak masih bersemangat memelihara sapi walaupun hanya sebagai pekerjaan sampingan.

Tabel 1. Hasil Analisa Laboratorium Amoniasi Urea Jerami Padi

\begin{tabular}{|c|c|c|}
\hline Kandungan & $\begin{array}{c}\text { Jerami Padi } \\
\text { Tanpa } \\
\text { Amoniasi }\end{array}$ & $\begin{array}{l}\text { Jerami Padi } \\
\text { Teramoniasi }\end{array}$ \\
\hline Protein Kasar (\%) & 3,45 & 6,66 \\
\hline Lemak (\%) & 1,2 & 1,21 \\
\hline Serat Kasar (\%) & 35,19 & 33,02 \\
\hline BETN & 37,27 & 21,76 \\
\hline Abu & 25,06 & 25,18 \\
\hline $\begin{array}{l}\text { Kandungan dinding sel } \\
(\mathrm{NDF} / \%)\end{array}$ & 79,8 & 75,09 \\
\hline Energi bruto (GE/Kcal/kg) & 3539,48 & 3927,36 \\
\hline
\end{tabular}


Tabel 1 menunjukkan bahwa kadar protein kasar pada jerami yang telah teramoniasi meningkat, hal ini juga terlihat pada kandungan serat kasar jerami menurun setelah mengalami amoniasi. Akibat dari kandungan protein yang meningkat menyebabkan kandungan energi bruto jerami yang telah teramonisasi juga meningkat sebesar $387,88 \mathrm{Kcal} / \mathrm{kg}$. Kandungan serat kasar jerami padi juga mengalami penurunan yang signifikan dengan perlakuan amoniasi, dengan perlakuan ini menyebabkan tingginya daya cerna jerami padi oleh ternak. Hal ini seperti pernyataan Cheeke (1999), yang menyatakan bahwa kandungan serat kasar mengalami penurunan karena teknik amoniasi dengan menggunakan urea sebagai sumber NPN dapat menghancurkan ikatanikatan lignin, selulosa, hemiselulosa dan silika yang merupakan faktor penyebab rendahnya daya cerna jerami padi bagi ternak.

Amoniasi jerami juga berdampak pada kecernaan zat-zat makanan pada jerami padi, seperti kandungan bahan kering, bahan organik, dinding sel, nutrien tercerna total, dan energi tercerna semuanya mengalami peningkatan setelah perlakuan amoniasi. Kecernaan jerami padi seperti terlihat pada Tabel 2.

Tabel 2. Kecernaan Zat-zat Makanan Jerami Padi

\begin{tabular}{lcc}
\hline \multicolumn{1}{c}{ Kecernaan } & $\begin{array}{c}\text { Jerami Padi } \\
\text { Tanpa Amoniasi }\end{array}$ & $\begin{array}{c}\text { Jerami Padi } \\
\text { Teramoniasi }\end{array}$ \\
\hline Bahan Kering (\%) & 40,65 & 50,09 \\
Bahan Organik (\%) & 50,57 & 60,51 \\
Dinding Sel/NDF (\%) & 46,51 & 60,51 \\
Nutrien tercerna total/TDN (\%) & 38,59 & 46,37 \\
Energi Tercerna/DE (Kcal/g) & 1,45 & 1,99 \\
\hline \multicolumn{2}{c}{ Sumber: Chuzaemi, S. dan Soejono, } & M. (1987) dalam Rahadi (2008).
\end{tabular}

Karena teknik amoniasi ini murah dan mudah dilakukan untuk peningkatan kadar protein pada pakan ternak, serta jerami mudah ditemukan dan selama ini menjadi limbah pertanian maka hal ini menjadi alasan dilakukannya kegiatan ini. Tujuan dari kegiatan ini adalah pemanfaatan jerami padi sebagai pakan ternak yang selama ini merupakan limbah pertanian dan umumnya di bakar dan untuk meningkatkan pengetahuan dan teknologi inovasi petani peternak tentang penggunaan jerami padi sebagai pakan dan bagaimana meningkatkan kualitasnya.

\section{METODE PELAKSANAAN}

\section{Waktu dan Tempat}

Kegiatan ini dilakukan pada hari Kamis, 30 Agustus 2018 di Kandang sapi Dusun Montong Are Tengah Desa Montong Are Kecamatan Kediri Kabupaten Lombok Barat.

\section{Alat dan Bahan}

Alat yang digunakan pada program ini adalah plastik ukuran besar dan bahan yang digunakan yaitu jerami, urea, dan starbio (micro organism).

\section{Bentuk Kegiatan}


Kegiatan ini dilakukan dengan menggunakan metode ceramah, dan diskusi kelompuk terfokus (Focus Group Discussion/FGD). Langkah ini dilakukan agar masyarakat sasaran dapat menerima informasi dengan baik dan dapat diterima dan dimengerti. Langkah awal yang dilakukan adalah dengan mengumpulkan warga terutama anggota kelompok tani ternak Pade Pacu untuk memberikan pemahaman mengenai pentingnya pakan ternak dengan teknik amoniasi. Selanjutanya masyarakat petani peternak diajak berpartisipasi langsung untuk mengolah jerami dengan teknik amoniasi yaitu dengan penambahan urea pada jerami. Tahapan kegiatan amoniasi jerami di Desa Montong Are seperti terlihat pada Gambar 1 - Gambar 5.

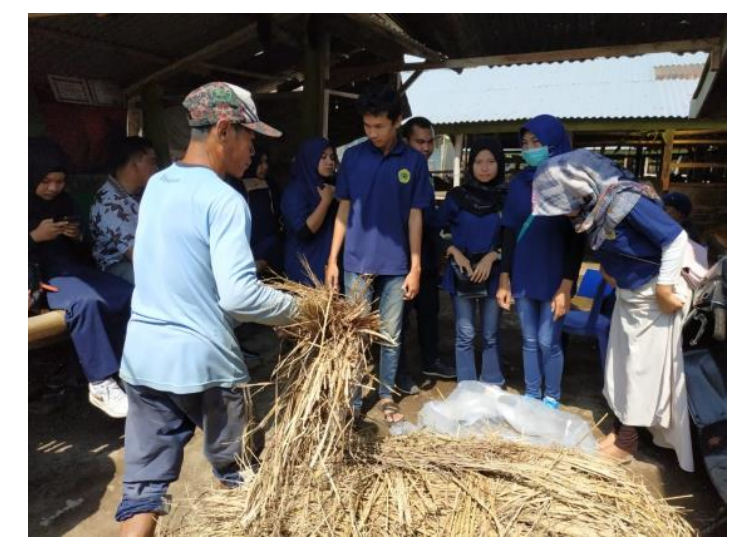

Gambar 1. Jerami padi yang berkualitas baik (artinya tidak membusuk ataupun basah karena terendam air) setelah panen dikumpulkan/ditumpuk disuatu tempat

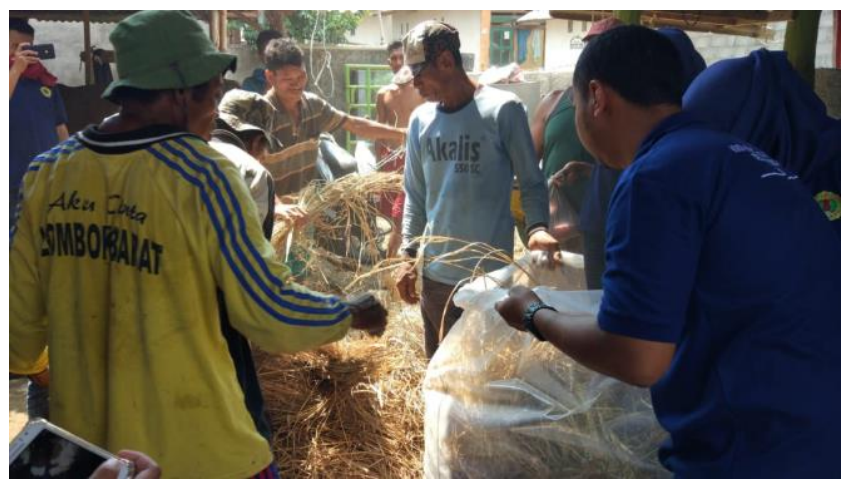

Gambar 2. Urea ditambahkan sebanyak $6 \%$ dari bobot jerami dengan cara ditabur langsung atau dilarutkan untuk kemudian disemprotkan merata diatas permukaan tumpukan. Misalnya jumlah jerami padi yang diolah sebanyak $100 \mathrm{~kg}$ maka urea yang dibutuhkan sebanyak $6 \mathrm{~kg}$. 


\section{Jurnal Warta Desa}

www.jwd.unram.ac.id

Vol. 1 NO. 1 April 2019

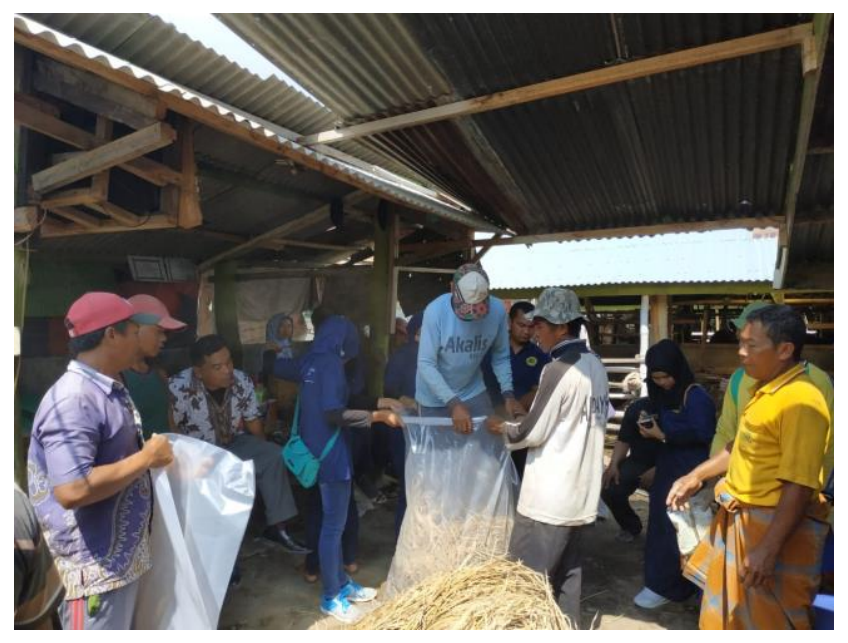

Gambar 3. Ditambahkan starter (microbio) dengan menaburkan dipermukaan tumpukan jerami. Starter yang digunakan adalah $100 \mathrm{~g}$ per $100 \mathrm{~kg}$ jerami.

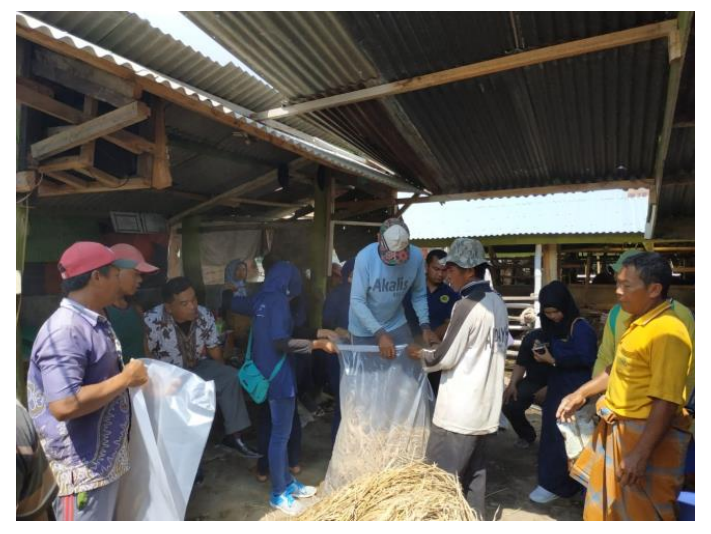

Gambar 4. Selanjutnya ditumpuk kembali jerami setinggi $\pm 25-30 \mathrm{~cm}$ diatasnya lalu ditebar urea dan starter seperti pada tahap 3 dan 4. Demikian seterusnya diulangi hingga tinggi tumpukan jerami mencapai 1-2 meter. 


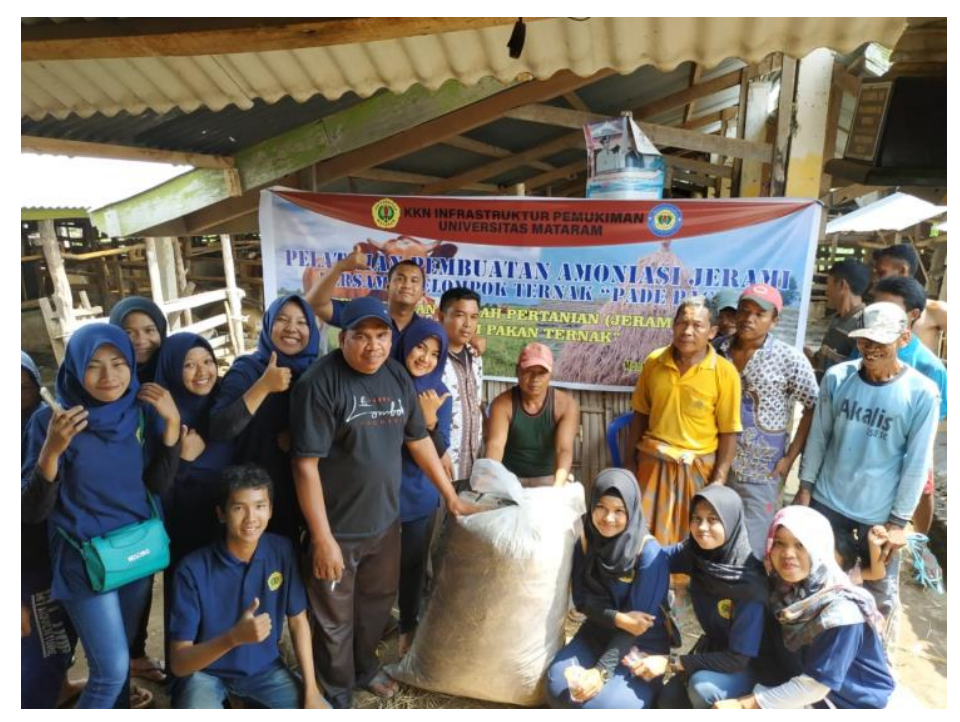

Gambar 5. Tumpukan jerami yang telah selesai, ditutup rapat dan didiamkan selama \pm 3 minggu (21 hari). Setelah 21 hari, tutup dibuka, dikering anginkan dan jerami padi amoniasi dapat disimpan ditempat penyimpanan pakan.

\section{HASIL DAN PEMBAHASAN}

Kegiatan dihadiri oleh kelompok tani ternak Pade Pacu dan dibantu oleh pihak dari pelayanan kesehatan hewan Kabupaten Lombok Barat. Adapun respon dari khalayak sasaran yakni kelompok tani ternak cukup baik dan memberikan respon yang positif terhadap materi yang diberikan. Faktor pendukung pada kegiatan ini adanya dukungan dari berbagai pihak seperti pemerintah desa, pemerintah Kabupaten Lombok Barat, antusiasnya para peternak Desa Montong Are, kepedulian para peternak akan lahan yang akan digunakan, bahan dan alat yang mudah didapat, dukungan motivasi dan bantuan dari teman-teman $\mathrm{KKN}$, waktu dan tempat yang cukup memadai.

Adapun faktor penghambat penerapan teknologi amoniasi ini adalah petani/peternak sebenarnya masih enggan memberikan jerami sebagai pakan ternak sapi, mengingat masih banyak terdapat hijauan. Tetapi dengan adanya kegiatan pelatihan ini baik melalui diskusi maupun demonstrasi langsung, maka petani peternak bisa secara langsung mengaplikasikannya. Petani peternak diberikan kesadaran bahwa pakan segar yang berasal dari rumput akan sulit didapat ketika musim kemarau tiba, sehingga dengan alternatif pakan dari jerami padi ini dapat memberikan alternatif lain untuk kebutuhan pakan ternak khusunya di musim kemarau. Kelebihan lain dari jerami hasil amoniasi ini juga dapat disimpan ditempat yang kering dalam waktu yang lama.

Teknik amoniasi termasuk perlakuan alkali yang dapat meningkatkan daya cerna jerami padi. Urea dalam proses amoniasi berfungsi untuk melemahkan ikatan lignoselulosa dan silika yang menjadi faktor penyebab rendahnya daya cerna jerami padi. Nitrogen yang berasal dari urea yang meresap dalam jerami mampu meningkatkan kadar amonia di dalam rumen sehingga tersedia substrat untuk memperbaiki tingkat dan efisiensi sintesis protein oleh mikroba.

Amoniasi merupakan salah satu perlakuan alkali untuk meningkatkan nilai cerna jerami padi. Menurut Bata (2008) jerami padi yang diberi perlakuan urea 4\% dan disimpan selama 4 minggu terjadi peningkatan daya cerna dari $35 \%$ menjadi $43,6 \%$ dan kandungan nitrogen total dari $0,48 \%$ 
menjadi $1,55 \%$. Langkah yang coba dilakukan adalah dengan memanfaatkan limbah pertanian terutama jerami padi karena Desa Montong Are merupakan daerah pertanian dimana jerami padi sering tidak dimanfaatkan bahkan terbuang. Melalui teknologi amoniasi dengan urea maka nilai gizi jerami masih dapat ditingkatkan sehingga dapat dimanfaatkan sebagai pakan ternak ruminansia khususnya sapi.

\section{KESIMPULAN}

Petani peternak sangat antusias terhadap materi yang diberikan tentang teknologi pengolahan jerami padi melalui amoniasi dengan urea sebagai pakan sapi yang berkualitas. Pemanfaatan jerami padi sebagai pakan ternak akan lebih menguntungkan karena dapat memanfaatkan limbah pertanian sehingga tidak terbuang percuma, disamping dapat meningkatkan ketersediaan pakan terutama pada saat rumput sulit diperoleh.

\section{UCAPAN TERIMA KASIH}

Kegiatan pelatihan pembuatan amoniasi jerami di Desa Montong Are Kecamatan Kediri Kabupaten Lombok Barat ini telah berhasil dilaksanakan. Hal ini karena partisipasidan dukungan masyarakat desa khususnya kelompok petani peternak "Pade Pacu". Dukungan juga berasal dari Dinas Peternakan Kabupaten Lombok Barat, baik berupa dukungan bahan dalam hal ini penggunaan efektif mikrobia (starter) dan petugas penyuluh peternakan. Dukungan Kepala Desa dan aparat Desa Montong Are juga menjadi penyebab bergairahnya kelompok petani peternak untuk mengikuti kegiatan ini. Selanjutnya suksesnya kegiatan ini tidak terlepas dari dukungan moril dari dosen pembimbing dan kelompok mahasiswa KKN di Desa Montong Are ini. Ucapan terima kasih juga kami khaturkan kepada Universitas Mataram dalam hal ini Lembaga Penelitian dan Pengabdian Kepada Masyarakat (LPPM) yang telah menempatkan kami di Desa Montong Are, dan kepada seluruh masyarakat Desa Montong Are Kecamatan Kediri Kabupaten Lombok Barat.

\section{DAFTAR PUSTAKA}

Chenost, M., dan C. Kayouli.1997. Roughage. 1997. Roughage Utilization in Warm Climates. ISBN 92-5103981-X. Rome : Food and Agriculture Organization of the United Nations. [cited 2007 Nov.30]. Available from : URL : http :/www/ Fao. Org/docrep/003/w4988e/W4988E01.htm. Diakses 2 September 2018.

Cheeke., Peter, R., 1999. Applied Animal Nutrition; Feed and Feeding. Third Edition. Prentice-Hall, Inc : New Jersey.

Balasubramanian, M.K. 2013. Potential utilization of rice straw for ethanol production by sequential fermentation of cellulose and xylose using Saccharomyces cerevisiae and Pachysolen tannophilus. International Journal of Science, Engineering, Technology and Research 2 (7): 1531-1535. ISSN: 2278 $-7798$

Mathius, I. W., dan Sinurat. A. P. 2001. Pemanfaatan bahan pakan inkonvensional untuk ternak. Wartazoa 11 (2): 20-31.

Kraidees, M. S. 2005. Influence of urea treatment and soybean meal (urease) addit ion on the utilization of wheat straw by sheep. AsianAust. J. Anim. Sci. 18 (7) : 957 - 965.

Muhammad Bata. 2008. Pengaruh Molases Pada Amoniasi Jerami Padi Menggunakan Urea Terhadap Kecernaan Bahan Kering dan Bahan Organik In Vitro. Agripet 8 (2) : $15-20$. 
Novita, C.I., A. Sudono, I. K. Sutama dan T. Tohermat. 2006. Produktivitas kambing peranakan etawa yang diberi ransum berbasis jerami padi fermentasi. Media Peternakan 29 (2) : 96 - 106.

Rahadi, S. 2008. Teknik Pembuatan Amoniasi Urea Jerami Padi Sebagai Pakan Ternak. Makalah PENERAPAN IPTEK Pemanfaatan Limbah Jerami Padi Melalui Teknologi Amoniasi untuk Mengatasi Kekurangan Pakan di Musim Kemarau, di Desa Montong Are Kec. Kediri Kab. Lombok Barat, 24 November 2018. Sumber : ilmuternak.wordpress.com/.../teknik-pembuatan-amo-niasi-urea-jerami-padisebagai-pakan-ternak/ Diakses 2 September 2018.

Sarnklong, C., Cone, J. W., Pellikaan, W., and Hendriks. W. H. 2010. Utilization of Rice Straw and Different Treatments to Improve Its Feed Value for Ruminants: A Review. Asian-Aust. J. Anim. Sci.

Sutrisno, C. I., Sulistyanto, Widyati S., Nurwantoro., Mukodin-ingsih, S., Surahmanto, dan Tristiarti. 2006. Peningkatan Kualitas Jerami Sebagai Pakan. [cited 2006 Dec. 10]. Avail-able from : URL : http://www.dikti.org/p36/abstrakHB/abstrakHB05. Pdf. Diakses 2 September 2018

Van Soest, P. 2006. Rice Straw, the Role of Silica and Treatments to Improve Quality. Animal Feed Science and Technology, 130 (14):137-171. ttp://doi.org/10.1016/j.anifeedsc i.2006.01.023 